\title{
Spatial and Temporal Analysis of Surface Water Quality in Relation to Marcellus Shale Gas Development in the Northern Panhandle of West Virginia
}

\author{
Rachel Yesenchak \\ West Virginia University, rey0002@mix.wvu.edu
}

Follow this and additional works at: https://researchrepository.wvu.edu/etd

Part of the Geochemistry Commons

\footnotetext{
Recommended Citation

Yesenchak, Rachel, "Spatial and Temporal Analysis of Surface Water Quality in Relation to Marcellus Shale Gas Development in the Northern Panhandle of West Virginia" (2018). Graduate Theses, Dissertations, and Problem Reports. 3744.

https://researchrepository.wvu.edu/etd/3744

This Thesis is protected by copyright and/or related rights. It has been brought to you by the The Research Repository @ WVU with permission from the rights-holder(s). You are free to use this Thesis in any way that is permitted by the copyright and related rights legislation that applies to your use. For other uses you must obtain permission from the rights-holder(s) directly, unless additional rights are indicated by a Creative Commons license in the record and/ or on the work itself. This Thesis has been accepted for inclusion in WVU Graduate Theses, Dissertations, and Problem Reports collection by an authorized administrator of The Research Repository @ WVU. For more information, please contact researchrepository@mail.wvu.edu.
} 
Spatial and Temporal Analysis of Surface Water Quality in Relation to Marcellus Shale Gas Development in the Northern Panhandle of West Virginia

\author{
Rachel Yesenchak \\ Thesis submitted \\ to the Eberly College of Arts and Sciences \\ at West Virginia University \\ in partial fulfillment of the requirements for the degree of \\ Master of Science in \\ Geology
}

Shikha Sharma, Ph.D., Chair

Timothy Carr, Ph.D.

Aaron Maxwell, Ph.D.

Department of Geology and Geography

Morgantown, West Virginia

2018

Keywords: surface water geochemistry, spatial analysis, Marcellus Shale Copyright 2018 Rachel Yesenchak 


\begin{abstract}
Spatial and Temporal Analysis of Surface Water Quality in Relation to Marcellus Shale Gas Development in the Northern Panhandle of West Virginia
\end{abstract}

\title{
Rachel Yesenchak
}

Pre-existing water chemistry data available from the West Virginia Department of Environmental Protection were used to examine temporal changes in surface water quality related to the onset of Marcellus Shale gas drilling activity in the state of West Virginia. Drilling is concentrated in the northwestern portion of the state. Watersheds were delineated for twelve discrete stream sampling locations in the Upper Ohio-Wheeling HUC-8 sub-basin, where shale gas drilling is prevalent. Kruskal-Wallis tests were deployed to compare pre- and post-drilling concentrations of conductivity, chloride, and total suspended solids for each location. Increased concentrations of these parameters are associated with surface water contaminated by shale gas drilling. Streams in this study show no significant temporal changes related to shale gas development. Correlation tests were used to identify possible relationships between water quality and different phases of the shale gas drilling process. Results of the analysis indicate that no relationship exists between these variables for the streams in this study. The nature of this analysis allows for identification of long-term water quality changes due to shale gas drilling but does not provide a mechanism for evaluating single point discharges or short-term contamination events. Studies of this type can also help identify potential sites where continuous monitoring sensors could be deployed in the future. 


\section{ACKNOWLEDGEMENTS}

First and foremost, I would like to thank Dr. Shikha Sharma for providing me with the opportunity to pursue this research and for her guidance, support, and patience throughout the process. I would also like to thank Dr. Timothy Carr and Dr. Aaron Maxwell for their advice and support during this endeavor.

Additionally, I'd like to thank my friends and family for their support and for enduring my chronic absences from events and get-togethers. I am grateful for the experiences I have had at WVU and especially for all the new friendships I have gained. Thank you to all the students, professors, and friends I have met over the last year and a half. I couldn't have done it without you! 


\section{TABLE OF CONTENTS}

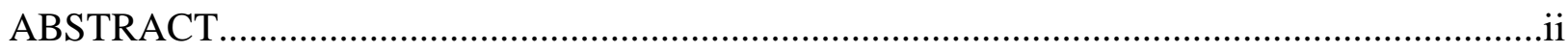

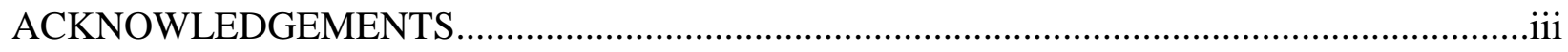

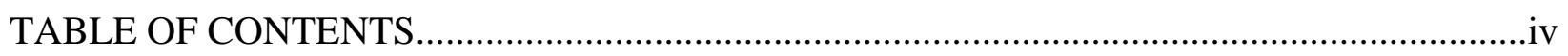

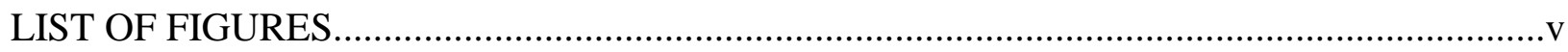

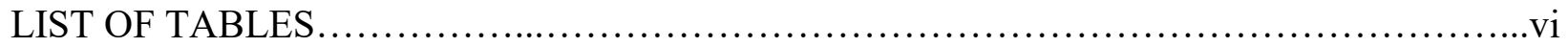

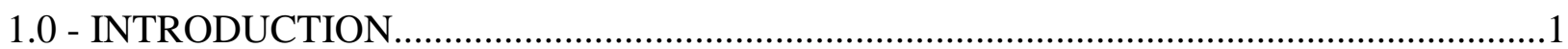

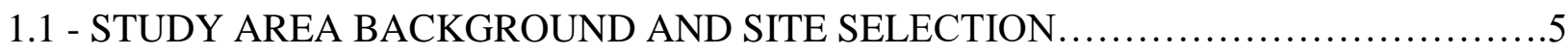

1.1.2 - GEOCHEMISTRY OF SURFACE WATERS IN THE STUDY AREA.................8

1.1.3 - GEOCHEMISTRY OF PRODUCED WATER FROM THE MARCELLUS SHALE..10

1.1.4 - INFLUENCES OF SHALE GAS DEVELOPMENT ON WATER QUALITY ..........12

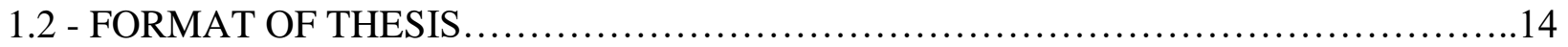

2.0 - SPATIAL AND TEMPORAL ANALYSIS OF SURFACE WATER QUALITY IN RELATION TO MARCELLUS SHALE GAS DEVELOPMENT IN THE NORTHERN

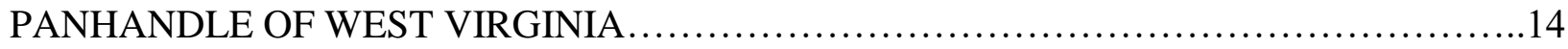

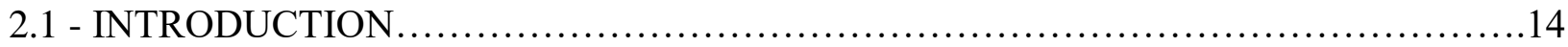

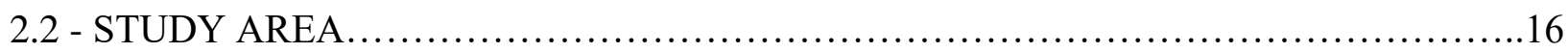

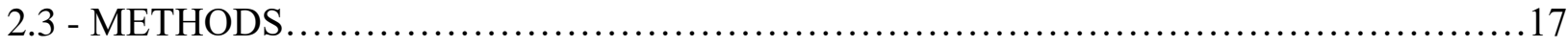

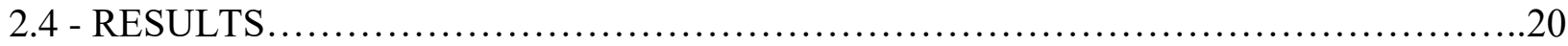

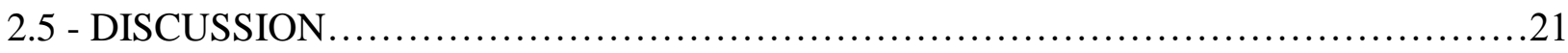

2.5.1 - TEMPORAL CHANGES IN WATER QUALITY .................................21

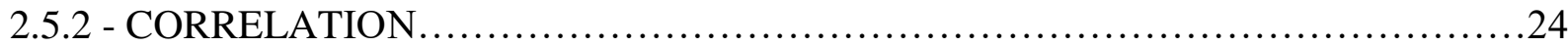

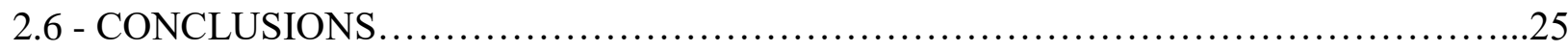

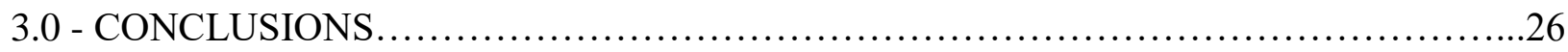

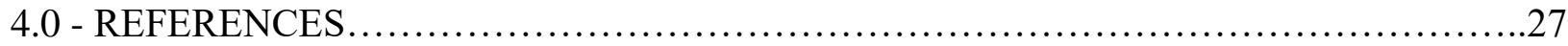

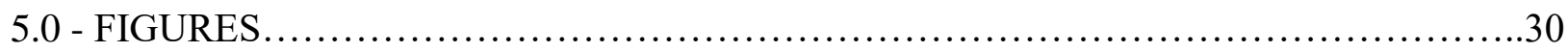

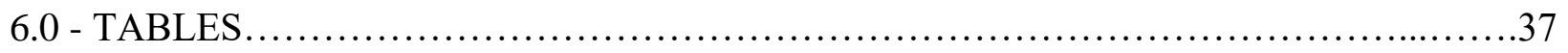




\section{LIST OF FIGURES}

FIGURE 1 - Horizontal Marcellus Shale gas well locations in the state of West Virginia..........30

FIGURE 2 - Study area showing water quality sampling locations and associated watersheds, color-coded to indicate control and non-control streams....................................... 31

FIGURE 3 - Kruskal-Wallis results for conductivity, chloride, and TSS.......................32

FIGURE 4 - Temporal conductivity plots for non-control vs. nearby control streams............33

FIGURE 5 - Temporal chloride plots for non-control vs. nearby control streams...............34

FIGURE 6 - Temporal TSS plots for non-control vs. nearby control streams.....................35

FIGURE 7 - Correlation plots for conductivity, chloride, and TSS............................36 


\section{LIST OF TABLES}

TABLE 1 - Kruskal-Wallis results.................................................. 37

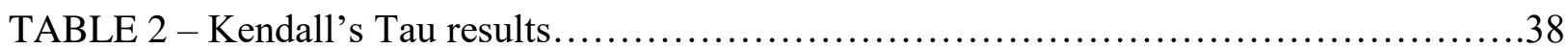




\section{0 - INTRODUCTION}

Hydraulic fracturing for natural gas has become a contentious issue, particularly in areas of shale gas drilling. Public perception of energy development is often influenced by political affiliation and emotionally charged images in the media, rather than scientific data. This has created a polarized debate, with one side touting the benefits of energy independence and job creation and the other side focusing on the potential for environmental degradation and human health consequences (Boudet et al., 2014; Choma et al., 2016). The tightening or loosening of unconventional gas drilling regulations has even become a cornerstone of political platforms for local, state, and federal candidates. Obfuscating the debate is the lack of clear, readily accessible data regarding the long-term benefits and drawbacks of unconventional drilling in shale regions. This study focuses on the environmental effects of Marcellus Shale gas development in the state of West Virginia.

Approximately 1,995 horizontal, hydraulically fractured natural gas wells have been drilled in the Marcellus Shale in West Virginia. Shale gas development in the state increased quickly after the first unconventional well was drilled by Chesapeake Appalachia, LLC in Marshall County in August 2007 (West Virginia Geological and Economic Survey, 2018). Figure 1 illustrates the locations of horizontal Marcellus Shale gas wells in West Virginia. Although coal is the main source of electricity generation in the state, natural gas has become the primary source on a national level. The U.S. Energy Information Administration expects this trend to continue for at least the next several decades. Shale gas production is expected to increase, accounting for approximately $39 \%$ of total domestic energy production by the year 2050 . This increase is likely to be fueled by the development of shale gas plays in the eastern U.S., namely the Marcellus and Utica shales (U.S. Energy Information Administration, 2018). To facilitate the responsible 
development of domestic natural gas resources, scientists and regulators must work together to understand the local effects of unconventional drilling.

Regional-based studies on hydraulic fracturing for natural gas are important because potential positive and negative impacts are dependent upon the local geology, environmental conditions, and economies of areas that are being developed. Additionally, unconventional shale gas drilling is exempt from portions of several federal environmental statutes, which leaves the bulk of regulation up to state and local officials. Hydraulic fracturing operations are exempt from the National Pollutant Discharge Elimination System permitting requirement for storm water related discharges under the Clean Water Act and certain regulations regarding hazardous waste under the Resource Conservation and Recovery Act. Operations that do not utilize diesel fuel are exempt from a portion of the Safe Drinking Water Act (U.S. EPA, 2018). These exemptions contribute to the unease surrounding hydraulic fracturing in the Marcellus Shale. Concerns over drinking water contamination run high and media scrutiny of this issue has increased over time. Regional studies of water quality in areas undergoing shale gas development can help quell public unease and inform the regulatory process for local and state officials.

Previous studies have been done to evaluate the effects of Marcellus Shale gas drilling on surface and ground water quality. These studies focus on methane and brine contamination of groundwater, surface water contamination due to produced water and sediment input, and the effects of wastewater treatment on downstream water resources. Most of these studies have been published as federal data reports or in specialized geochemistry journals and are not easily understood by the general public or regulatory officials, as they rely on complex geochemical and isotopic analysis and elaborate statistical models. Additionally, the methods often involve expensive sampling and laboratory testing procedures (Entrekin et al., 2011; Olmstead et al., 
2013; Osborn et al., 2011; Pelak \& Sharma, 2014; Warner et al., 2012; Warner et al., 2013, Wilson et al., 2014). These prohibitive costs prevent a large-scale evaluation of water quality in Marcellus Shale gas development regions. To facilitate a more widespread understanding of the environmental effects of shale gas drilling, it is necessary to devise strategies that utilize routine water quality data being acquired by state and federal agencies as part of their various monitoring programs to assess any changes in water quality related to shale gas drilling. Three major advantages of this approach are 1) there is no expensive data analysis and collection involved, 2) long term water quality data from both the pre- and post-drilling periods are readily available for several sampling sites, and 3) it can help identify potential sites where continuous water monitoring sensors might be deployed in the future. Further, it is also important for water quality analytical results to be presented to regulatory officials and the general public in a clear, easy to understand format. Visual displays, such as maps and diagrams, can enhance learning, promote comprehension of text passages, and improve recall of information (Verdi et al., 1997). Therefore, this study focuses on mining and analyzing publicly-available, pre-existing water quality data and displaying results in a series of easily interpretable charts and maps that may help inform regulators and community members about possible water quality changes related to Marcellus Shale gas drilling in Brooke, Ohio, and Marshall counties in the northern panhandle of West Virginia.

There are two general categories of natural gas production based on the types of geologic formations where the gas resides. "Conventional gas" is trapped in highly permeable rock layers such as sandstone and limestone that are capped by an impermeable layer. Vertical wells are economical for the extraction of conventional gas since the high permeability of rock layers allows the gas to flow freely. "Unconventional gas" is contained within rock layers that have 
very low permeability, such as shale or fine-grained sandstone. Extraction of unconventional gas requires more advanced drilling techniques and hydraulic fracturing, in order to free the gas trapped within the pore spaces of the rock (National Energy Technology Laboratory, 2013). The Marcellus Shale is considered an unconventional source.

The Marcellus Shale is one of the largest shale gas plays in the United States, spanning an area of approximately 95,000 square miles within the Appalachian basin (U.S. Energy Information Administration, 2017). The Marcellus underlies parts of Ohio, Maryland, West Virginia, Virginia, Pennsylvania, and New York. It ranges in thickness from about 700 feet in the east to less than a foot in the west. The Marcellus Shale is a Middle Devonian formation, overlying the Onondaga Limestone and underlying the Mahantango Formation. It is a dark, fissile, carbonaceous shale interbedded with limestone. The formation is rich in pyrite and often contains carbonate concretions (Bruner \& Smosna, 2011). The U.S. Geological Survey has estimated that the Marcellus Shale contains 84,198 billion cubic feet of undiscovered natural gas (Coleman, et al., 2011).

The number of hydraulically fractured shale gas wells in the United States increased dramatically when hydraulic fracturing technology was combined with directional drilling, around the year 2000. (U.S. EPA, 2016). The unconventional drilling process begins with the construction of a well pad, usually comprising an area of about 5 acres in the Marcellus region. Vertical wells are drilled to a depth just above the target formation. Then, each well is deviated until it runs horizontally through the target formation for thousands of feet. In the Marcellus, the drilling process typically takes 15 to 30 days. As the wells are drilled, metal casings are cemented in place to protect groundwater resources from gas and fluid migration. The lateral casings are then perforated using explosives and hydraulic fracturing fluid is introduced into the well under high 
pressure to fracture the rock. The fluid contains a proppant (usually sand) that keeps the newlycreated fractures open, so gas can flow into the well. The freed gas, along with hydraulic fracturing fluid and formation brines, flow through the well and return to the surface (National Energy Technology Laboratory, 2013). In West Virginia, the median volume of fracturing fluid used in Marcellus wells between January 2011 and February 2013 was 5,012,238 gallons. Up to $30 \%$ of the injected fluid volume is returned to the surface within the first 10 years following hydraulic fracturing. Additional volumes of fluid will return to the surface throughout the well's lifetime. This fluid, a combination of the original hydraulic fracturing fluid and formation brine, is known as "produced water" (U.S. EPA, 2016). Brines within the Marcellus Shale are highly saline with total dissolved solids (TDS) ranging from 10-343 g/L (Warner et al., 2012). In turn, produced water from Marcellus gas wells also displays elevated concentrations of TDS as compared to surface and shallow groundwater in the Appalachian basin. Chloride is the dominant anion in produced water, but concentrations of other ions, such as sodium, magnesium, barium, and calcium are elevated as well. Compared to coal mine drainage, sulfate concentrations are relatively low. Produced water also contains elevated concentrations of radioactive elements, such as radium (Ziemkiewicz \& He, 2015).

Produced water is temporarily stored in tanks or impoundments on-site and then removed via trucks or pipelines. Produced water from the Marcellus is often recycled for use in other hydraulic fracturing operations, but it may also be treated by specially permitted wastewater treatment plants or injected underground into suitable geologic formations in certain states (U.S. EPA, 2016). There is concern that hydraulic fracturing fluids or produced water can contaminate local surface water and groundwater, including those sources that are used as drinking water 
supplies. Contamination pathways may include casing failures, leaking impoundments and tanks, accidental spills, and improper wastewater disposal (U.S. EPA, 2016; Olmstead et al., 2013).

\section{1 - STUDY AREA BACKGROUND AND SITE SELECTION}

Unconventional Marcellus Shale gas drilling in West Virginia is most prevalent in the northwestern part of the state. This study focuses on surface water quality within the West Virginia portion of the Upper Ohio-Wheeling HUC-8 watershed. This study area was selected based on two criteria: the number of horizontal Marcellus Shale gas wells within the catchment and the availability of pre-existing water quality data. The use of pre-existing water quality data allows for a direct comparison between pre-drilling and post-drilling water quality at several discrete locations.

Data regarding locations and drilling dates for both vertical and horizontal Marcellus Shale gas wells were downloaded from the West Virginia Geological and Economic Survey (West Virginia Geological and Economic Survey, 2018). Well locations were plotted in ArcMap (ESRI, v 10.4.1) using coordinate information. The horizontal wells were then extracted from the dataset using the Select by Attributes tool and were converted into a new shapefile. Spatial analysis of the horizontal well file determined that the Upper Ohio-Wheeling and the Little MuskingumMiddle Ohio watersheds contain the largest number of gas wells in the state (491 and 744 wells, respectively).

Water quality data were downloaded using the West Virginia Department of Environmental Protection's (WV DEP) online query tool. The data were examined to identify discrete stream locations with long-term sampling records that contained sampling events from both the pre- 
drilling and post-drilling periods. An attempt was made to utilize data from the Environmental Protection Agency's Water Quality Portal, but no long-term sampling records were available for streams in the highest density drilling areas. Based on the availability of water quality data, the Upper Ohio-Wheeling watershed was identified as the most suitable study area. At the time of analysis, the West Virginia portion of this watershed contained 491 horizontal Marcellus Shale gas wells. The drainage area for this portion of the watershed is approximately 562 square miles. Land use is dominated by deciduous forests and farmland with small percentages of urban and residential areas (WV DEP, 2009). Sampling records consisting of both pre- and post-drilling data were available for twelve streams within the catchment. The study area and water quality sampling locations are shown in Figure 2.

The study area lies entirely within the Appalachian Plateau physiographic province. The plateau is mainly comprised of Pennsylvanian and Permian age sedimentary rocks, including alternating layers of sandstone, siltstone, shale, and marine limestone. Minable, bituminous coal is prevalent in the study area. The strata are generally flat-lying with an abundance of deeply incised streams (West Virginia Geological and Economic Survey, 2017). Three major orogenic events spanning a period of 200 million years helped shape the topography of the Appalachian Plateau: the Middle-Late Ordovician Taconic orogeny, the Middle Devonian-Lower Mississippian Acadian orogeny, and Pennsylvanian-Permian Alleghenian orogeny. Crustal thickening in the east during the Acadian orogeny provided a source for siliciclastic sediments that eventually settled in the Appalachian basin (Bruner \& Smosna, 2011).

The study area is a sub-basin of the Upper Ohio River basin and contains tributaries that drain directly into the Ohio River. The entire Ohio River basin encompasses a drainage area of 205,000 square miles. The Ohio River spans 981 miles starting in Pittsburgh, PA, at the 
confluence of the Monongahela and Allegheny rivers and ending where it joins the Mississippi River in Cairo, Illinois. The Ohio River supplies drinking water to over 5 million people. Pollution sources include runoff from urban and agricultural areas, abandoned coal mine drainage, and industrial sources (Ohio River Valley Water Sanitation Commission, 2018). The first horizontal Marcellus gas well in the Ohio River basin was drilled by Range Resources in 2005. As of 2015, over 6,000 horizontal wells had been drilled in the basin (Ohio River Valley Water Sanitation Commission, 2015).

Published literature suggests that produced water from the Marcellus Shale has a significantly different geochemical makeup than the surface and shallow ground waters in the Appalachian region (Chapman et al., 2012; Ziemkiewicz et al., 2015; Warner et al., 2012). This study exploits those differences to better understand whether streams in the study area have experienced geochemical changes as a result of escalating Marcellus Shale gas drilling. Additionally, increased sedimentation has been associated with Marcellus Shale gas development activities, including well pad and road construction (Olmstead et al., 2013; Entrekin et al., 2011). It is hypothesized that a direct comparison of pre-drilling and post-drilling water quality parameter concentrations can help identify contamination due to the sustained input of produced water or drill-site related sediments.

\subsection{2 - GEOCHEMISTRY OF SURFACE WATERS IN THE STUDY AREA}

As with all surface water, the geochemistry of streams in the study area is largely controlled by the local geology and the chemical composition of precipitation in the basin. Naturally occurring reactions between rocks and acidic rainfall, mineral precipitation, dissolution of gases like 
carbon dioxide, reduction and oxidation, and the breakdown of organic matter can influence surface water, leading to spatial and seasonal variations in water chemistry (Drever, 1997). In addition to naturally occurring controls on water chemistry, streams may be influenced by anthropogenic factors. Land use in the Upper Ohio-Wheeling watershed is dominated by deciduous forest and farmland, with small percentages of urban and residential areas. Streams in the study area are influenced by a multitude of point and non-point sources of pollution related to human activities. Effluent from wastewater treatment plants and municipal storm sewer system discharges are common point-sources. Non-point sources include agricultural runoff, failing septic systems, urban runoff, and increased sedimentation from construction activities, logging operations, and farming. Additionally, the study area has been subjected to a long history of surface and underground coal mining and conventional oil and gas development, which has contributed to chronic impairment of surface water quality (WV DEP, 2009).

Abandoned mine drainage is prevalent in the study area due to current and historic coal mining. Mine drainage normally has an acidic $\mathrm{pH}$, though it can also be neutral or alkaline. Acidic mine drainage occurs through a series of chemical reactions resulting from the dissolution of the mineral pyrite after coming into contact with water in an aerobic environment. Pyrite is a common inclusion in coal seams and surrounding rocks in the Appalachian basin. After being exposed to water and air, the pyrite is oxidized to produce ferrous iron and hydrogen ions, which create acidity in the system. Further reactions can then occur, generating ferric iron products and additional acidity. The acidity in the system can cause additional reactions releasing zinc, aluminum, and manganese from adjacent rocks. The cycle of chemical reactions and acid generation will continue until all the pyrite has been consumed. If sufficient alkalinity is present in the system, the acid may be neutralized. Carbonate rocks and minerals, like dolomite and 
calcite are the most common sources of alkalinity in natural systems. Acid mine drainage is characterized by low $\mathrm{pH}$ and high concentrations of total dissolved solids, iron, sulfate, aluminum, and manganese. The metals may precipitate out of solution, so they are not always a reliable way to distinguish mine drainage. However, sulfate is highly soluble and chemically stable in most natural waters, so it can be used to help identify mine drainage impacted streams (Sams \& Beer, 2000; Benjamin, 2015; Merovich et al., 2007).

\subsection{3 - GEOCHEMISTRY OF PRODUCED WATER FROM THE MARCELLUS SHALE}

Produced water from the Marcellus Shale has a chemical makeup that is distinct from surface waters in the study area. It is a combination of hydraulic fracturing fluid, deep formation brines, and potentially dissolved minerals from the shale or neighboring rock formations. Fracturing fluid is largely composed of freshwater obtained locally or brought in by truck. The amount of fluid needed to hydraulically fracture a well can vary from less than 74,000 gallons to over 6 million gallons. Water comprises between $90-97 \%$ of the volume of hydraulic fracturing fluid injected into a Marcellus Shale gas well. Chemical additives make up no more than $2 \%$ of the fracturing fluid, but relatively large quantities of these chemicals may be present on the drill site. Additives are used to adjust various properties of the fluid. They can be used to change the $\mathrm{pH}$, adjust viscosity, and inhibit scale or the growth of bacteria. Common additives include hydrochloric acid, methanol, and petroleum distillates. Proppant makes up the remaining volume of hydraulic fracturing fluid. Most often, the proppant is comprised of quartz sand, but manmade materials like ceramic particles may also be used. The purpose of proppant is to hold open the fractures created by injecting fluids into the well at high pressure, so the gas can flow out of the low permeability shale (U.S. EPA, 2016). 
Produced water from the Marcellus Shale is characterized by high concentrations of total dissolved solids (TDS), at times exceeding 150,000 mg/L (Haluszczak et al., 2013). Contributing to the elevated TDS levels, are high concentrations of chloride, sodium, and other ions such as calcium, strontium, barium, and bromide. Published literature suggests that the TDS constituent of produced water is the result of fracturing fluid mixing with and coming to equilibrium with saline brines within the shale formation (Haluszczak et al., 2013; Warner et al., 2012; Olmstead et al., 2013). Appalachian brines likely formed from the evaporation of seawater to the point of halite oversaturation. The brines then became enriched in calcium as dolomitization with carbonate rocks occurred. Interaction with local rocks and dilution altered the brine composition in various ways. This evolution of brines resulted in varying TDS concentrations and high $\mathrm{Br} / \mathrm{Cl}$ ratios (Warner et al., 2012). Appalachian brines are also depleted in sulfate relative to coal mine drainage. $\mathrm{Br} / \mathrm{Cl}$ ratios, $\mathrm{SO} 4 / \mathrm{Cl}$ ratios, and bromide concentrations have been used to distinguish between produced water and coal mine drainage contamination. The concentrations of dominant ions in produced water increase over the life of the well, though the volume of water being produced decreases over time (Wilson et al., 2014; Ziemkiewicz et al., 2015).

The nature of the data being used in this analysis prohibits the use of $\mathrm{Br} / \mathrm{Cl}$ ratios to pinpoint produced water inputs. Bromide was not a part of regular sampling activities for the WV DEP and only a few scattered results exist for recent years. However, $\mathrm{SO} / \mathrm{Cl}$ ratios could be used to help rule out mine drainage input in areas experiencing water quality changes. 


\subsection{4 - INFLUENCES OF SHALE GAS DEVELOPMENT ON WATER QUALITY}

Numerous studies have been undertaken to investigate the impacts of hydraulic fracturing on water quality. The results of those studies have been mixed. Proposed pathways for contamination include leaking well casings, migration of brines or fracturing fluid into groundwater through newly created subsurface fractures, leaking tanks and impoundments, accidental spills on-site or during wastewater transport, and improper waste disposal. Warner et al. (2012) investigated the possible migration of deep formation brine into groundwater aquifers in northeastern Pennsylvania. They found no correlation between saline intrusions in groundwater and the location of shale gas wells, suggesting that geologic conditions in the study area supported the natural migration of brines (Warner et al., 2012). A geochemical and isotopic study in the Monongahela River Basin also found no correlation between the intensity of shale gas drilling and water quality parameter values, indicating that at the very least, there was no chronic surface water contamination occurring in the area (Pelak \& Sharma, 2014).

An analysis of drilling violations in Pennsylvania revealed that, between 2008-2012, only 17\% of water contamination complaints implicating oil and gas activity were proven to actually be caused by drilling activity. These cases involve both conventional and unconventional wells. According to the Pennsylvania Department of Environmental Protection, unconventional gas wells have the capacity to impact a larger number of water resources at one time than conventional gas wells. An incident in Dimock, PA saw 18 residential groundwater wells contaminated by methane likely sourced from a single gas well. Of 161 cases of water contamination proven to be caused by drilling activity between 2008- 2012, 23\% reported contamination by brine components and $4 \%$ reported contamination by sediments or drill cuttings (Brantley et al., 2014). 
Studies focused on wastewater treatment plants accepting shale gas waste in Pennsylvania found that downstream levels of chloride are elevated relative to upstream concentrations. Elevated levels of radium in stream sediments were documented immediately downstream of the effluent discharge (Olmstead et al., 2013; Warner et al., 2013). Studies focused on well-site related sedimentation have found that elevated levels of total suspended solids (TSS) are positively correlated with upstream gas well density (Olmstead et al., 2013; Entrekin et al., 2011). Using regression analysis, Olmstead et al. (2013) determined that increasing the density of upstream well pads by 1 standard deviation resulted in a 5\% increase in downstream TSS. However, the study found no correlation between the density of upstream gas wells and downstream chloride concentrations (Olmstead et al., 2013).

In 2016, the U.S. Environmental Protection Agency released a report detailing their findings regarding the impacts of hydraulic fracturing on drinking water supplies. The report identifies contamination pathways present during each stage of hydraulic fracturing and cites documented incidents of water contamination. The report also references a previous EPA review of spill data reported by state agencies and drilling operators. They found that produced water was the most commonly reported material involved in a spill and that leaking impoundments or tanks were the most common spill source. Of 225 reported produced water spills, at least $13 \%$ were able to reach surface water resources. The spill volumes ranged from about 170- 74,000 gallons. The report concluded that drilling-related water contamination does occur but highlighted the need for more data to determine the extent of the problem and to aid in mitigation (U.S. EPA, 2016; U.S. EPA, 2015). 


\title{
1.2 - FORMAT OF THESIS
}

Chapter 1 of this thesis contains relevant background information, study area details, and a literature review. Chapter 2 is written in manuscript style formatted for submission to Environmental Earth Sciences.

2.0 - SPATIAL AND TEMPORAL ANALYSIS OF SURFACE WATER QUALITY IN RELATION TO MARCELLUS SHALE GAS DEVELOPMENT IN THE NORTHERN PANHANDLE OF WEST VIRGINIA

\begin{abstract}
Pre-existing water chemistry data available from the West Virginia Department of Environmental Protection were used to examine temporal changes in surface water quality related to the onset of Marcellus Shale gas drilling activity in the state of West Virginia. Drilling is concentrated in the northwestern portion of the state. Watersheds were delineated for twelve discrete stream sampling locations in the Upper Ohio-Wheeling HUC-8 sub-basin, where shale gas drilling is prevalent. Kruskal-Wallis tests were deployed to compare pre- and post-drilling concentrations of conductivity, chloride, and total suspended solids for each location. Increased concentrations of these parameters are associated with surface water contaminated by shale gas drilling. Streams in this study show no significant temporal changes related to shale gas development. Correlation tests were used to identify possible relationships between water quality and different phases of the shale gas drilling process. Results of the analysis indicate that no relationship exists between these variables for the streams in this study. The nature of this analysis allows for identification of long-term water quality changes due to shale gas drilling but does not provide a mechanism for evaluating single point discharges or short-term contamination events. Studies of this type can also help identify potential sites where continuous monitoring sensors could be deployed in the future.
\end{abstract}

\section{1 - INTRODUCTION}

Hydraulic fracturing has become a polarizing issue, particularly in areas of Marcellus Shale gas extraction. The debate is often driven by fears surrounding the environmental effects of shale gas 
development (Boudet et al., 2014; Choma et al., 2016). Obfuscating the discourse is a lack of clear, accessible data regarding the long-term environmental effects of this drilling. Marcellus Shale gas development in the state of West Virginia began in 2007, when the first horizontal well was drilled in Marshall County. Since then, over 1,995 horizontal, hydraulically fractured natural gas wells have been drilled in the state (West Virginia Geological and Economic Survey, 2018).

To extract gas from a low-permeability reservoir like the Marcellus Shale, directional drilling technology is combined with hydraulic fracturing. About five million gallons of fracturing fluid are injected into the well under high pressure to fracture the shale, allowing gas to flow into the well. Fresh water constitutes $90-97 \%$ of fracturing fluid, with small volumes of chemical additives and sand or other proppants accounting for the remaining 3-10\% (U.S. EPA, 2016). As the freed gas flows through the well and returns to the surface, it is accompanied by fluids known as "produced water". Produced water is a combination of the original hydraulic fracturing fluid and deep formation brines. About $20-25 \%$ of the injected fluid volume will return to the surface shortly after hydraulic fracturing is complete, with smaller volumes returning throughout the well's lifetime (National Energy Technology Laboratory, 2013). Produced water from the Marcellus Shale is characterized by high concentrations of total dissolved solids (TDS), at times exceeding 150,000 mg/L (Haluszczak et al., 2013). Contributing to the elevated TDS levels, are high concentrations of chloride, sodium, and other ions such as calcium, strontium, barium, and bromide. Radionuclides can also be present. Published literature suggests that the TDS constituent of produced water is the result of fracturing fluid mixing with and coming to equilibrium with saline brines within the shale formation (Haluszczak et al., 2013; Warner et al., 2012; Olmstead et al., 2013). There is concern that hydraulic fracturing fluids or produced water can contaminate local surface or groundwater, including those sources that are used as drinking 
water supplies. Contamination pathways may include failure of protective well casings, leaking impoundments and storage tanks, accidental spills, and improper wastewater disposal (U.S. EPA, 2016; Olmstead et al., 2013; Entrekin et al., 2011). Additionally, there is evidence that drilling activity may increase downstream concentrations of total suspended solids (TSS). Increased sedimentation can have negative effects on stream biota and cause damage to drinking water treatment systems (Olmstead et al., 2013; Entrekin et al., 2011).

The purpose of this study was to determine if increasing Marcellus Shale gas development has caused detectable changes to surface water quality in the northern panhandle of West Virginia, where much of the state's drilling is concentrated. A direct statistical comparison of pre- and post-drilling water quality at several discrete locations was used to identify temporal changes that may be associated with drilling activity. Additionally, a nonparametric correlation analysis was used to determine whether changes in water quality parameters were associated with different stages of the drilling process.

\section{2 - STUDY AREA}

Unconventional Marcellus Shale gas drilling in West Virginia is most prevalent in the northwestern part of the state. This study focuses on surface water quality within the West Virginia portion of the Upper Ohio-Wheeling 8-digit hydrologic unit code (HUC-8) subwatershed. The drainage area for this portion of the watershed is approximately 562 square miles. Land use is dominated by deciduous forests and farmland, with small percentages of urban and residential use (West Virginia Department of Environmental Protection, 2009). The study area lies entirely within the Appalachian Plateau physiographic province. It is mainly comprised 
of Pennsylvanian and Permian age sedimentary rocks, including alternating layers of sandstone, siltstone, shale, and marine limestone. Minable, bituminous coal is prevalent in the study area. The strata are generally flat-lying with an abundance of deeply incised streams (West Virginia Geological and Economic Survey, 2017). The study area is a sub-basin of the Upper Ohio River Basin and contains tributaries that drain directly into the Ohio River, which supplies drinking water to over 5 million people (Ohio River Valley Water Sanitation Commission, 2018).

Streams in the study area are influenced by a multitude of point and non-point sources of pollution related to human activities. Effluent from wastewater treatment plants and municipal storm sewer system discharges are common point-sources. Non-point sources include agricultural runoff, failing septic systems, urban runoff, and increased sedimentation from construction activities, logging operations, and farming. Additionally, the study area has been subjected to a long history of surface and underground coal mining and conventional oil and gas development, which has contributed to chronic impairment of surface water quality (West Virginia Department of Environmental Protection, 2009). At the time of this analysis, 491 horizontal, hydraulically fractured Marcellus Shale gas wells had been drilled in the study area (West Virginia Geological and Economic Survey, 2018). The study area and gas well locations are shown in Figure 2.

\section{$2.3-$ METHODS}

To facilitate a direct comparison between pre- and post-drilling water quality at discrete stream locations, this study utilizes pre-existing water quality data. Data was downloaded from the West Virginia Department of Environmental Protection (WV DEP) using their online query tool. 
Water quality sampling locations were plotted in ArcMap (ESRI, v 10.4.1) and compared to Marcellus Shale gas well locations to identify streams located in high-density drilling areas. Data regarding gas well locations and drilling dates were downloaded from the West Virginia Geological and Economic Survey. Water quality data were visually inspected to identify streams with sampling records that contained both pre- and post-drilling data. Observations with missing dates or parameter values were deleted from the record. Samples taken on the same day at the same sampling location were averaged to create a single record. The detection limit was substituted for measurements falling below the detection limit.

A total of six streams were chosen for statistical analysis. These streams are located in areas of high-density Marcellus Shale gas drilling. An additional six streams were chosen to act as "control" streams. These streams have no Marcellus Shale gas wells within their catchment area. The control streams act as a baseline to visually compare temporal trends between areas of no drilling and areas of shale gas development. Figure 2 illustrates the locations of control and noncontrol stream sampling locations and their corresponding watersheds.

The traditional parameters used to identify water contamination related to Marcellus Shale gas drilling include TDS, chloride, sodium, bromide, radionuclides, and TSS (Haluszczak et al., 2013; Warner et al., 2012; Olmstead et al., 2013; Entrekin et al., 2011; Wilson et al., 2014). However, the data being utilized for this study prohibits the use of many of these parameters. TDS, sodium, bromide, and radionuclides were not a part of regular WV DEP sampling activities. This study uses conductivity as a proxy for TDS. A known positive relationship exists between the two parameters and it is common for TDS to be estimated from conductivity results (McCutcheon et al., 1993). This study also makes use of chloride and TSS data collected by the WV DEP. 
The most prominent effects of shale gas development on water quality should occur within the catchment area associated with each stream sampling location (Olmstead et al., 2013). For this reason, individual watersheds were delineated for each sampling point. Watersheds were delineated using a 3-meter digital elevation model mosaicked by the West Virginia GIS Technical Center. TauDEM (version 5.3.7) was used to create a hydrologically correct elevation grid and to delineate the watersheds using water quality sampling locations as pour points. The Drop Analysis function was used during delineation to objectively determine stream networks and contributing areas.

Spud dates and permitting dates were determined for all gas wells falling within a sampling location's watershed. Increases in downstream TSS are associated with the construction phase of Marcellus Shale gas wells. This phase includes land-clearing activities for well pad and road construction. Most of this activity would take place between the permitting date and spud date for the first well on a well pad. Increases in downstream conductivity and chloride are associated with wells that have already been drilled (Olmstead et al., 2013; Entrekin et al., 2011). Using this logic, the pre- and post- drilling groups for the TSS data were determined using the permit date for the first well in each watershed. For conductivity and chloride, the spud date for the first well in each watershed was used. Kruskal-Wallis tests were deployed in RStudio (version 3.5.1) for each watershed to determine whether there had been a significant change in water quality between the pre- and post-drilling periods. This study uses a significance level of 0.05 and the null hypothesis states that the distribution of values in the pre- and post-drilling groups is the same.

To further investigate the link between Marcellus Shale gas drilling and water quality, correlation analysis was also performed using RStudio. An approach similar to the one 
undertaken by Olmstead et al. (2013) was used to determine if a relationship exists between specific water quality parameters and different stages of well development. TSS samples were paired with the number of well pads in the construction phase within the watershed on the date of each observation. Conductivity and chloride values were paired with the number of spudded wells that existed within the watershed on the date of each observation. Kendall's Tau was used to detect correlation with a significance level of 0.05 and a null hypothesis stating that no relationship exists between the variables.

\section{$2.4-$ RESULTS}

Results of the Kruskal-Wallis tests are summarized in Table 1 and illustrated by Figure 3. Pvalues for conductivity, chloride, and TSS range from $0.04331-1,0.03115-0.6216$, and $0.1558-0.7484$, respectively. The p-values are insignificant for all streams except the north fork of Short Creek. The null hypothesis is accepted for these streams. The north fork of Short Creek has a p-value of 0.04331 for conductivity and 0.03115 for chloride. The null hypothesis is rejected for these parameters. Sampling records for Stull Run did not include pre-drilling data for chloride or TSS, so only conductivity values were used for analysis of this stream. Temporal plots of control vs. non-control streams for each parameter are shown in Figures 4-6. No obvious differences in temporal trends exist between the control streams and the streams located in areas of Marcellus Shale gas drilling activity.

Results of the Kendall's Tau tests are summarized in Table 2 and illustrated by scatter plots in Figure 7. The correlation coefficients for conductivity, chloride, and TSS vary between $-0.32-$ $0.01,-0.33-0.5$, and $-0.08-0.06$, respectively. The corresponding p-values are all insignificant, 
ranging from $0.12-0.96$ for conductivity, $0.12-0.75$ for chloride, and $0.73-0.78$ for TSS. Using a significance level of 0.05 , the null hypothesis is accepted in all cases.

\section{5 - DISCUSSION}

\subsection{1 - TEMPORAL CHANGES IN WATER QUALITY}

The use of pre-existing water quality data in this analysis allows for a direct comparison of predrilling and post-drilling water quality at discrete stream locations. This design helps eliminate spatial variation in water quality measurements. Instead, analysis is focused on temporal variables associated with Marcellus Shale gas drilling activities. If streams in the study area are experiencing sustained input of produced water or drilling-related sediments, water quality parameter values should shift over time to reflect these inputs. However, the nature of the data used in this analysis prevents the identification of short-term contamination events, like single spills of produced water.

Produced water from the Marcellus Shale contains exceptionally high concentrations of TDS. A previous study by Ziemkiewicz et al. (2015) found that produced water samples from the study area and surrounding locations had TDS concentrations ranging from 8,840 - 154,000 mg/L. Chloride concentrations in produced water are also elevated relative to surface waters in the area. Produced water samples from the study area and surrounding locations had chloride concentrations ranging from 4,700 - 79,000 mg/L (Ziemkiewicz et al., 2015). Therefore, TDS and chloride concentrations would be expected to increase in streams contaminated by produced water (Olmstead et al., 2013; Entrekin et al., 2011; Warner et al., 2013; Wilson et al., 2014). Since the current dataset does not allow for a temporal analysis of TDS, conductivity is used as a 
proxy. If TDS concentrations within a stream are increasing, conductivity will increase as well (McCutcheon et al., 1993).

Conductivity values for all streams range from $232-5271 \mathrm{uS} / \mathrm{cm}$ in the pre-drilling period and $239-2972 \mathrm{uS} / \mathrm{cm}$ in the post-drilling period. Chloride values range from $3-277 \mathrm{mg} / \mathrm{L}$ in the pre-drilling period and $2-199 \mathrm{mg} / \mathrm{L}$ in the post-drilling period. Kruskal-Wallis p-values are insignificant for conductivity and chloride in all streams except the north fork of Short Creek (Table 1). This indicates that there was no change in the distribution of these parameter values between the pre- and post-drilling periods. If streams in the study area were receiving sustained input of produced water due to increasing Marcellus Shale gas development, we would expect post-drilling conductivity and chloride concentrations to be significantly higher than pre-drilling concentrations. This is not the case for streams used in this study.

Kruskal-Wallis p-values are significant for conductivity and chloride in the north fork of Short Creek (0.04331 and 0.03115, respectively). This indicates that there is a significant difference in the distribution of parameter values between the pre- and post-drilling period. The median value for conductivity decreased from $1,226 \mathrm{uS} / \mathrm{cm}$ in the pre-drilling period to $748.5 \mathrm{uS} / \mathrm{cm}$ in the post-drilling period. Likewise, median chloride values decreased from $64 \mathrm{mg} / \mathrm{L}$ to $26 \mathrm{mg} / \mathrm{L}$. This result suggests that, like other streams in the study area, the north fork of Short Creek has not received sustained inputs of produced water. Decreasing conductivity and chloride values in surface water can result from various changes within the watershed. Data obtained from the National Land Cover Database indicates that land cover has remained relatively constant between the pre- and post-drilling periods. The catchment for the north fork of Short Creek remains dominated by deciduous forest and farmland. GIS data obtained from the WV DEP indicates that two surface mine reclamation projects began during the interval between pre- and 
post-drilling stream sampling. Mine land remediation could reduce downstream conductivity but is unlikely to cause a significant decrease in chloride concentrations. The most likely explanation for the decrease in chloride (and by association, conductivity) is the establishment of Total Maximum Daily Loads (TMDLs). In 2009, the WV DEP established TMDLs for chloride and fecal coliform in the north fork of Short Creek. TMDL establishment is required by the Clean Water Act for all streams whose contaminant concentrations exceed allowable limits for the stream's designated use. TMDLs are intended to reduce specified stream contaminants to an acceptable level by allocating discharge allowances to known point and non-point sources of contamination (WV DEP, 2016).

Downstream increases in total suspended solids have also been associated with Marcellus Shale gas development. Increased sedimentation is likely related to the construction of well pads, impoundments, roads, and pipelines. Construction of these features involves removing vegetation and clearing land, while also increasing the amount of impervious surface within the watershed (Olmstead et al., 2013; Entrekin et al., 2011). If streams in the study area are receiving increased sediment loads due to increasing Marcellus Shale gas development, TSS values should increase in the post-drilling period. Kruskal-Wallis p-values for TSS are insignificant for all streams in this analysis. This suggests that streams in the study area are not experiencing significant, long-term increases in sedimentation due to Marcellus Shale gas development. 


\subsection{2 - CORRELATION}

Kendall's Tau was used to test for correlation between specific water quality parameters and different stages of Marcellus Shale gas development. Downstream increases in conductivity and chloride would likely be associated with the hydraulic fracturing and shale gas recovery phases, when vast quantities of produced water are being managed (Olmstead et al., 2013; Entrekin et al., 2011). Correlation tests were performed to identify possible relationships between the number of gas wells in these phases and conductivity and chloride concentrations. The gas well data set does not provide specific dates for these phases, so the spud date is used to determine the number of wells in each watershed that could be paired with conductivity/chloride concentrations on the date of each observation. The p-values for these correlation tests are insignificant for all streams. This indicates that there is no correlation between the number of wells post-spud and concentrations of conductivity or chloride for the streams in this analysis.

Previous studies have associated shale gas development with increases in downstream sedimentation. The most significant increases in sedimentation would likely occur during the construction phase for each well pad within the watershed (Olmstead et al., 2013; Entrekin et al., 2011). To aid in quantifying the number of well pads in construction within a watershed on the date of each TSS observation, Google Earth imagery was used in conjunction with individual well locations to determine which wells shared a pad. The construction phase for each well pad was then determined to be the interval between the date of the first permitted well and the date of the first spudded well on each pad. P-values for correlation tests involving TSS were insignificant for all streams. This indicates that there is no significant relationship between TSS concentrations and the number of well pads in development within the watersheds used for this analysis. 


\section{$2.6-$ CONCLUSIONS}

Results of Kruskal-Wallis tests for five streams located in areas of Marcellus Shale gas development indicate no significant change in conductivity, chloride, or TSS concentrations between the pre-drilling and post-drilling period. One stream showed a significant decrease in median values of conductivity and chloride between the pre- and post-drilling periods. This is likely due to the establishment of TMDLs for chloride within the stream. Results of Kendall's Tau correlation tests suggest that there is no relationship between water quality and stages of Marcellus Shale gas well development for the streams in this analysis. While results indicate that streams in the study area do not show evidence of long-term contamination due to shale gasrelated activities, this analysis cannot rule out short-term incidents of contamination. To capture incidents such as individual produced water spills and short-term sedimentation increases, it is necessary to deploy continuous water quality monitoring techniques. However, this study demonstrates that pre-existing data can be useful for identifying long-term water quality changes at discrete locations related to shale gas drilling or other activities within watersheds. 


\section{$3.0-$ CONCLUSIONS}

Pre-existing data were used to examine temporal changes in surface water quality related to the onset of Marcellus Shale gas drilling. Kruskal-Wallis tests were deployed to compare pre- and post-drilling concentrations of conductivity, chloride, and total suspended solids for six discrete stream locations. Results indicated that there were no significant changes in these parameters between the pre- and post-drilling period for five out of six streams. The sixth stream, north fork of Short Creek, showed a significant decrease in median values for conductivity and chloride. This decrease is likely related to the establishment of TMDLs in 2009, though it is possible that other changes within the watershed could be responsible. Results of correlation analysis indicated no relationships between water quality parameters and different stages of shale gas development within the study area.

Overall, this analysis provides no evidence of long-term contamination related to Marcellus Shale gas drilling for streams in the study area. However, stream samples were collected at wide and inconsistent intervals. Data of this nature cannot be used to rule out short-term incidents of contamination such as single spills of produced water or short-lived episodes of increased sedimentation. Additionally, the sample size was small and may not be representative of the entire population of streams located in high-density drilling areas. Future studies should incorporate data from various federal and state agencies, watershed groups, and universities to fill in temporal gaps and create a more robust sampling record. Expanding analysis to other basins may also yield better quality data and provide a greater understanding of the environmental effects of shale gas development in the state of West Virginia. 


\section{0 - REFERENCES}

Benjamin, M.M. (2015). Water Chemistry. Long Grove, Illinois: Waveland Press, Inc.

Boudet, H., Clarke, C., Bugden, D., Maibach, E., Roser-Renouf, C., Leiserowitz, A. (2014). "Fracking" controversy and communication: Using national survey data to understand public perceptions of hydraulic fracturing. Energy Policy, 65, 57-57.

Brantley, S.L, Yoxtheimer, D., Arjmand, S., Grieve, P., Vidic, R., Pollak, J., Llewellyn, G.T., Abad, J., Simon, C. (2014). Water resource impacts during unconventional shale gas development: The Pennsylvania experience. International Journal of Coal Geology, 126, 140-156.

Bruner, K., Smosna, R. (2011). A Comparative Study of the Mississippian Barnett Shale, Fort Worth Basin, and Devonian Marcellus Shale, Appalachian Basin. DOE-NETL Report.

Chapman, E.C., Capo, R.C., Stewart, B.W., Kirby, C.S., Hammack, R.W., Schroeder, K.T., Edenborn, H.M. (2012). Geochemical and Strontium Isotope Characterization of Produced Waters from Marcellus Shale Natural Gas Extraction. Environmental Science \& Technology, 46 (6), 3545-3553.

Choma, B.L., Hanoch, Y., Currie, S. (2016). Attitudes toward hydraulic fracturing: The opposing forces of political conservatism and basic knowledge about fracking. Global Environmental Change, 38, 108-117.

Coleman, J.L., Milici, R.C., Cook, T.A., Charpentier, R.R., Kirschbaum, Mark, Klett, T.R., Pollastro, R.M., and Schenk, C.J. (2011). Assessment of undiscovered oil and gas resources of the Devonian Marcellus Shale of the Appalachian Basin Province. U.S. Geological Survey Fact Sheet 2011-3092.

Drever, J.I. (1997). The Geochemistry of Natural Waters: Surface and Groundwater Environments. New Jersey: Prentice Hall.

Entrekin, S., Evans-White, M., Johnson, B., Hagenbuch, E. (2011). Rapid expansion of natural gas development poses a threat to surface waters. Frontiers in Ecology and the Environment, 9 (9), 503-511.

Haluszczak, L.O., Rose, A.W., Kump, L.R. (2013). Geochemical evaluation of flowback brine from Marcellus gas wells in Pennsylvania, USA. Applied Geochemistry, 28, 55-61.

McCutcheon, S.C., Martin, J.L. and T.O. Barnwell, Jr. (1993). Water Quality. In D. Maidment (Ed.), Handbook of Hydrology. New York, NY: McGraw-Hill.

Merovich, G., Stiles, J., Petty, J., Ziemkiewicz, P., Fulton, J. (2007). Water Chemistry-Based Classification of Streams and Implications for Restoring Mined Appalachian Watersheds. Environmental Toxicology and Chemistry, 26 (7), 1361-1369. 
National Energy Technology Laboratory. (2013). Modern Shale Gas Development in the United States: An Update. U.S. Department of Energy, Washington, DC.

Ohio River Valley Water Sanitation Commission. (2015). Hydraulic Fracturing in the Ohio River Basin. Prepared by Stephen M. Braun.

Ohio River Valley Water Sanitation Commission. (2018). "River Facts", http://www.orsanco.org/river-facts/: Accessed February 3, 2018.

Olmstead, S.M., Muehlenbachs, L.A., Shih, J.S., Chu, Z., Krupnick, A.J. (2013). Shale gas development impacts on surface water quality in Pennsylvania. Proceedings of the National Academy of Sciences of the United States of America, 110 (13), 4962-4967.

Osborn, S. G., Vengosh, A., Warner, N. R., \& Jackson, R. B. (2011). Methane contamination of drinking water accompanying gas-well drilling and hydraulic fracturing. Proceedings of the National Academy of Sciences of the United States of America, 108 (20), 8172-6.

Pelak, A.J., Sharma, S. (2014). Surface water geochemical and isotopic variations in an area of accelerating Marcellus Shale gas development. Environmental Pollution, 195, 91-100.

Sams, J.I., Beer, K.M. (2000). Effects of Coal-Mine Drainage on Stream Water Quality in the Allegheny and Monongahela River Basins-Sulfate Transport and Trends. U.S. Geological Survey Water-Resources Investigations Report 1999-4208.

U.S. Energy Information Administration. (2017). Marcellus Shale Play: Geology review. U.S. Energy Information Administration, Washington, DC.

U.S. Energy Information Administration. (2018). Annual Energy Outlook 2018. U.S. Energy Information Administration, Washington, DC.

U.S. Environmental Protection Agency. (2015). Review of state and industry spill data: Characterization of hydraulic fracturing-related spills. EPA Report, (EPA/601/R14/001), Office of Research and Development, Washington, DC.

U.S. Environmental Protection Agency. (2016). Hydraulic Fracturing for Oil and Gas: Impacts from the Hydraulic Fracturing Water Cycle on Drinking Water Resources in the United States. EPA Report, (EPA/600/R-16/236ES), Office of Research and Development, Washington, DC.

U.S. Environmental Protection Agency. (2018). "Unconventional Oil and Natural Gas Development”, https://www.epa.gov/uog: Accessed February 3, 2018.

Verdi, M., Johnson, J., Stock, W., Kulhavy, R., Whitman-Ahern, P. (1997). Organized Spatial Displays and Texts: Effects of Presentation Order and Display Type on Learning Outcomes. The Journal of Experimental Education, 65 (4), 303-317. 
Warner, N.R., Jackson, R.B., Darrah, T.H., Osborn, S.G., Down, A., Zhao, K., White, A., Vengosh, A. (2012). Geochemical evidence for possible natural migration of Marcellus Formation brine to shallow aquifers in Pennsylvania. Proceedings of the National Academy of Sciences of the United States of America, 109 (30), 11961-11966.

Warner, N.R., Christie, C.A., Jackson, R.B., Vengosh, A. (2013). Impacts of Shale Gas Wastewater Disposal on Water Quality in Western Pennsylvania. Environmental Science and Technology, 47, 11849-11857.

West Virginia Department of Environmental Protection. (2009). Total Maximum Daily Loads for Selected Streams in the Upper Ohio South Watershed, West Virginia. Prepared by Tetra Tech, Charleston, WV.

West Virginia Department of Environmental Protection. (2016). 2016 West Virginia Draft Section 303(d) List With Decision Rationale and Supplements.

West Virginia Geological \& Economic Survey. (2017). "Physiographic Provinces of West Virginia", http://www.wvgs.wvnet.edu/www/maps/pprovinces.htm: Accessed January 5, 2018.

West Virginia Geological and Economic Survey. (2018). "Selected Shale-Gas Resources", http://www.wvgs.wvnet.edu/www/datastat/devshales.htm: Accessed July 10, 2018.

Wilson, J., VanBriesen, J., Wang, Y. (2014). Sources of high total dissolved solids to drinking water supply in southwestern Pennsylvania. Journal of Environmental Engineering, 140 (5).

Ziemkiewicz, P.F., He, Y.T. (2015). Evolution of water chemistry during Marcellus Shale gas development: A case study in West Virginia. Chemosphere, 134, 224-231 


\section{0 - FIGURES}

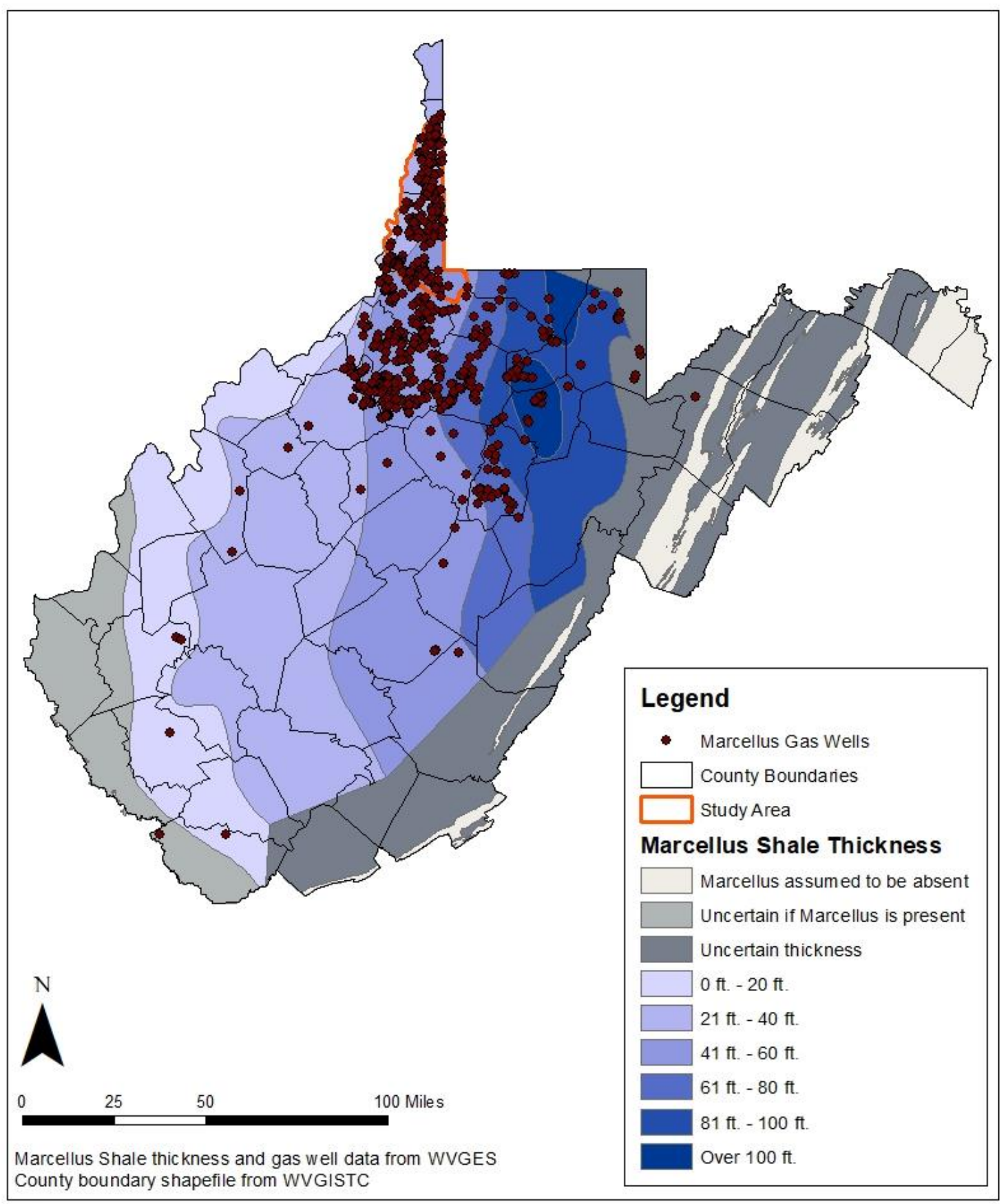

FIGURE 1 - Horizontal Marcellus Shale gas well locations in the state of West Virginia 


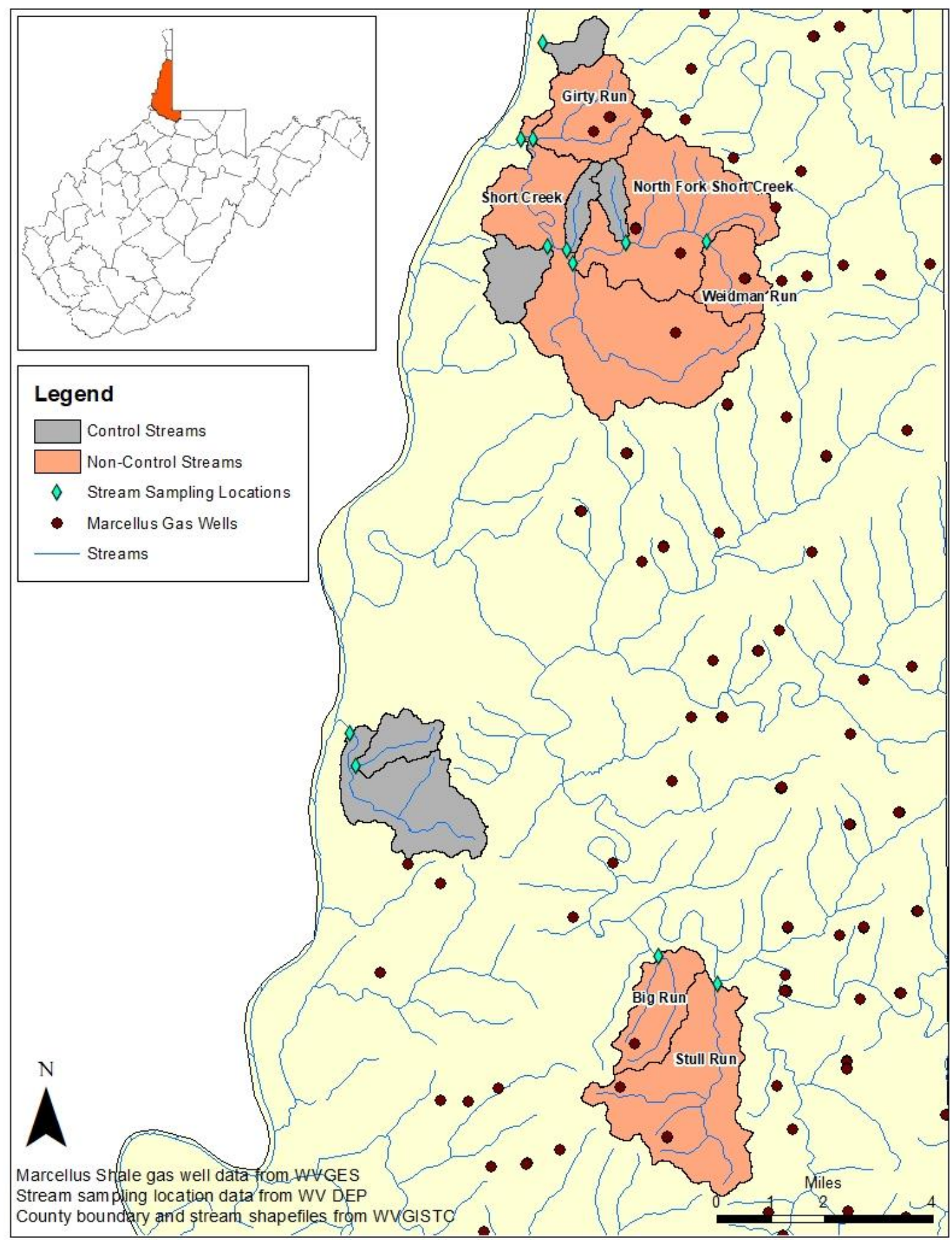

FIGURE 2 - Study area showing water quality sampling locations and associated watersheds, color-coded to indicate control and non-control streams 

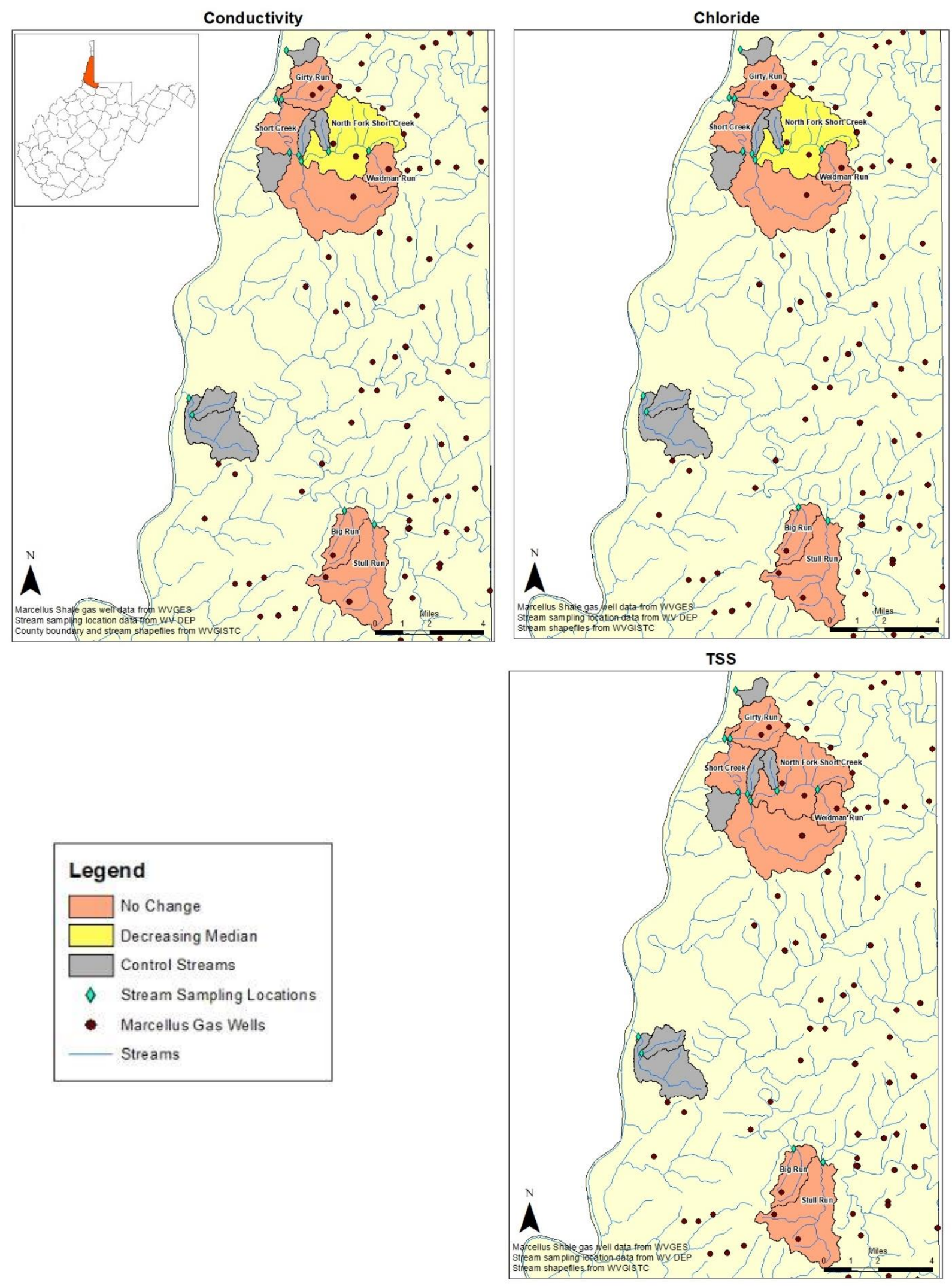

FIGURE 3 - Kruskal-Wallis results for conductivity, chloride, and TSS 

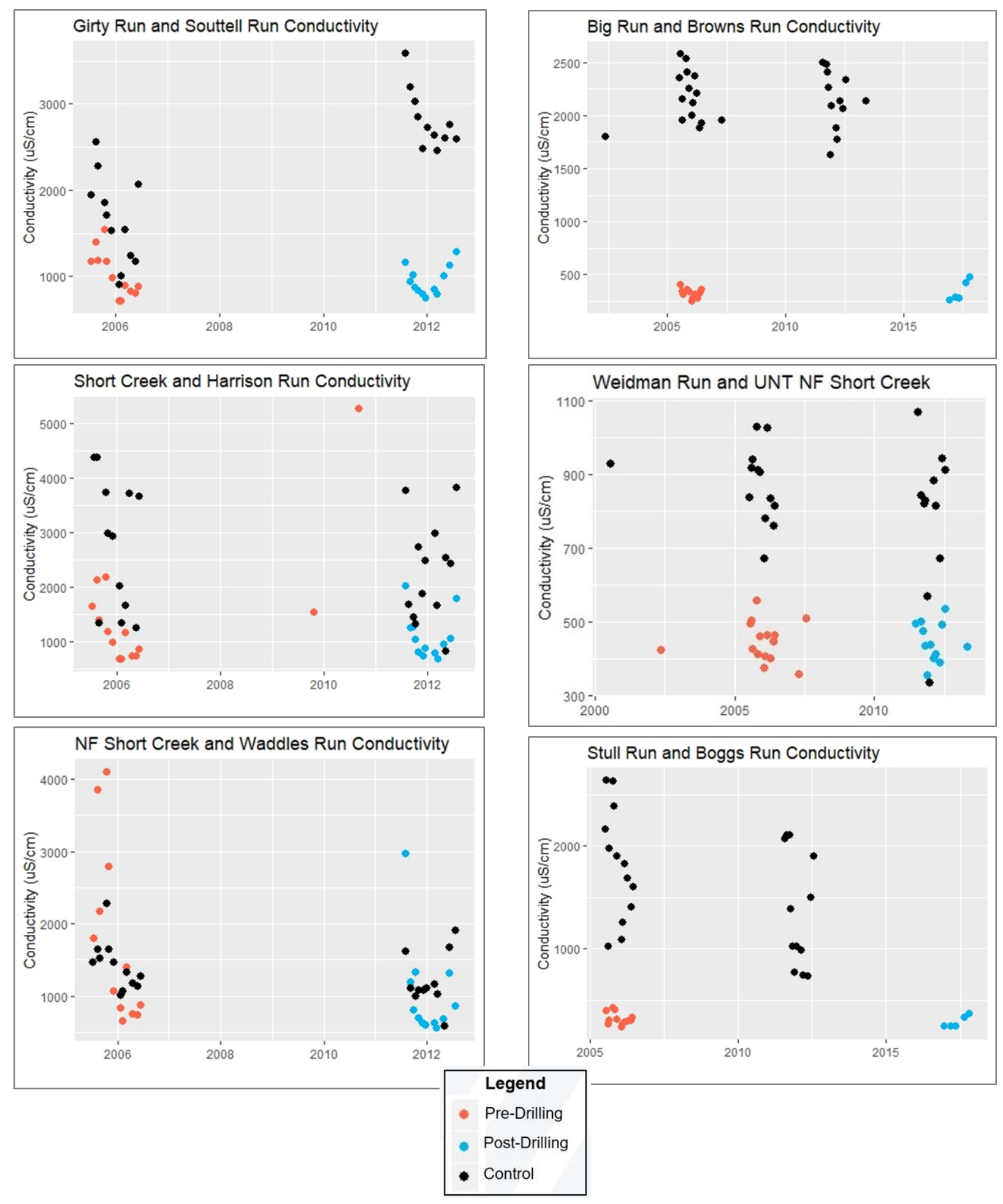

FIGURE 4 - Temporal conductivity plots for non-control vs. nearby control streams 

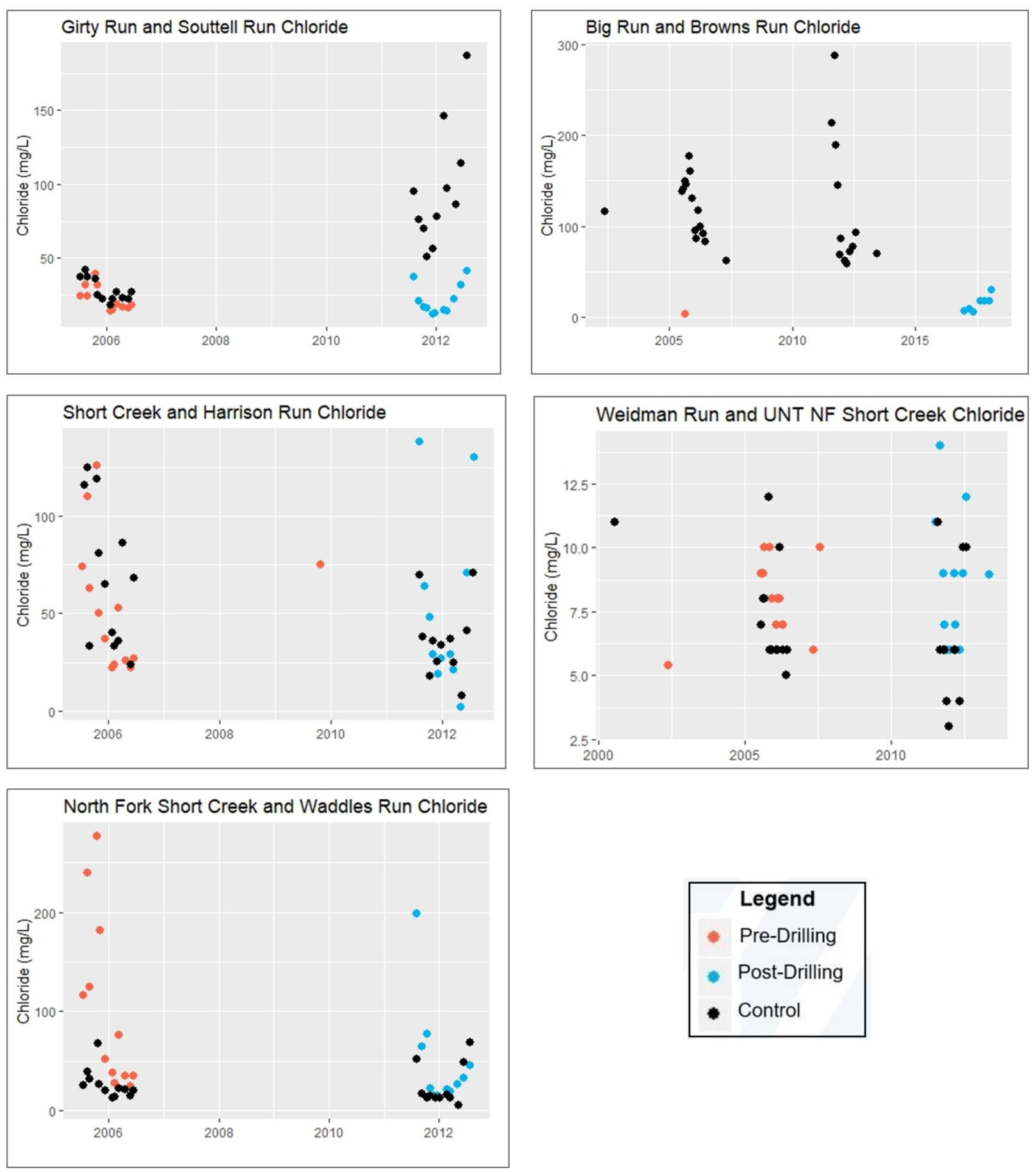

FIGURE 5 - Temporal chloride plots for non-control vs. nearby control streams 

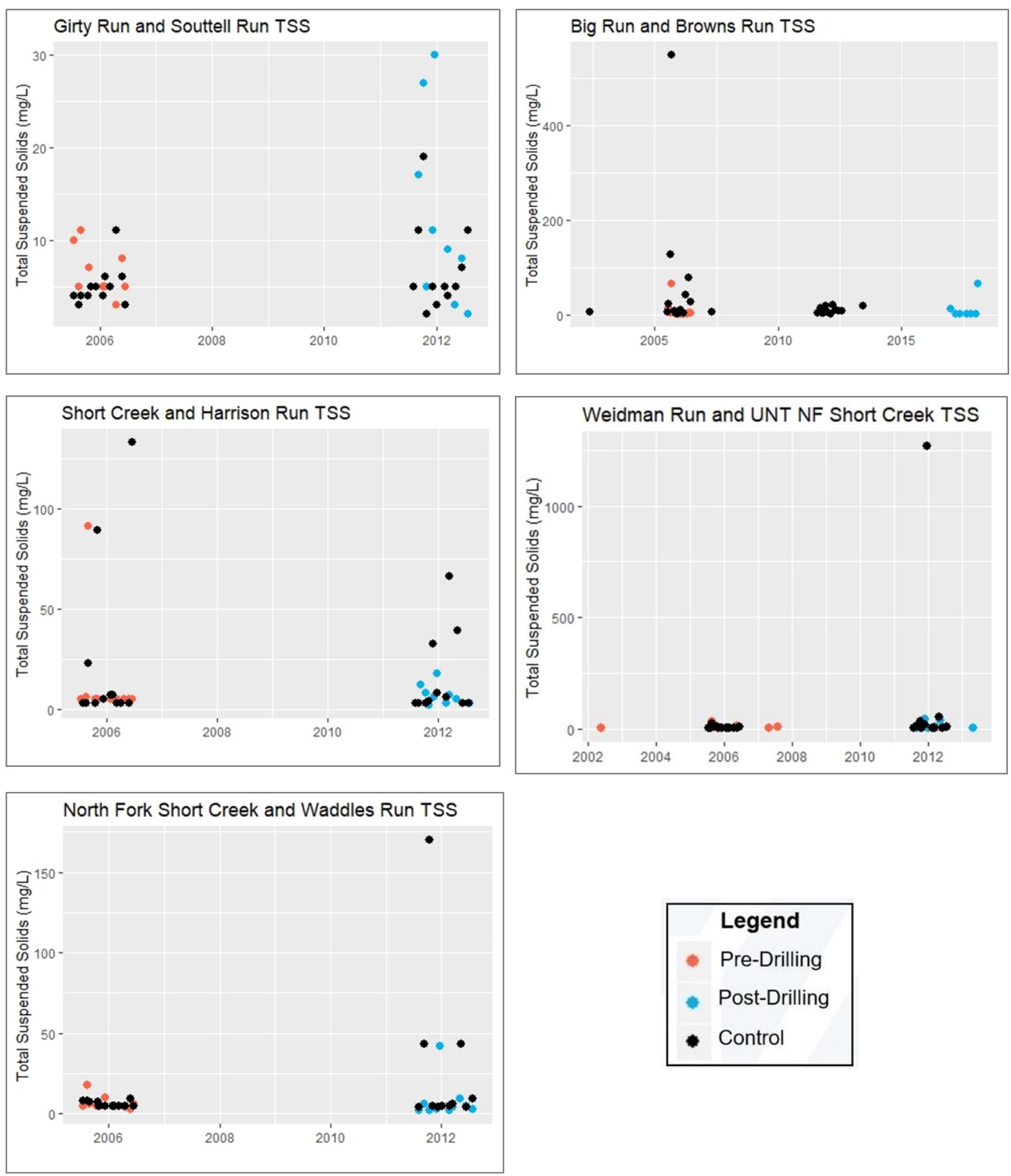

FIGURE 6 - Temporal TSS plots for non-control vs. nearby control streams 

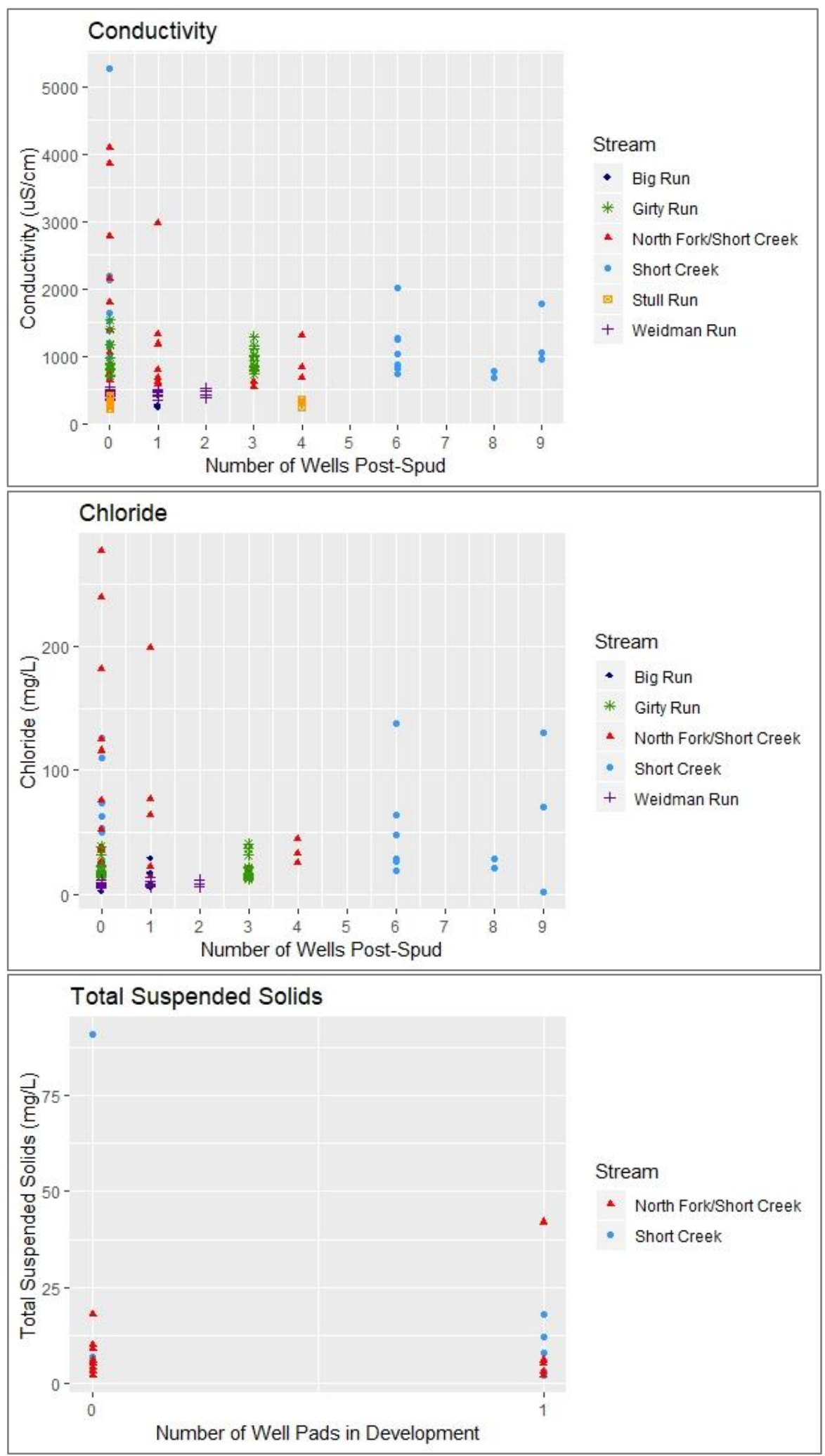

FIGURE 7 - Correlation plots for conductivity, chloride, and TSS 


\begin{tabular}{|l|c|c|c|}
\hline \multicolumn{1}{|c|}{$\begin{array}{c}\text { Stream } \\
\text { Name }\end{array}$} & $\begin{array}{c}\text { Conductivity } \\
\text { p-value }\end{array}$ & $\begin{array}{c}\text { Chloride } \\
\text { p-value }\end{array}$ & $\begin{array}{c}\text { TSS } \\
\text { p-value }\end{array}$ \\
\hline Big Run & 0.9548 & 0.1266 & 0.3574 \\
\hline Girty Run & 0.5637 & 0.4406 & 0.335 \\
\hline North Fork/ Short Creek & 0.04331 & 0.03115 & 0.1558 \\
\hline Short Creek & 0.5037 & 0.6849 & 0.6708 \\
\hline Stull Run & 0.3428 & N/A & N/A \\
\hline Weidman Run & 1 & 0.6216 & 0.7484 \\
\hline
\end{tabular}

TABLE 1 - Kruskal-Wallis results 


\begin{tabular}{|c|c|c|}
\hline Stream/ Parameter & $\begin{array}{c}\text { Correlation } \\
\text { Coefficient }\end{array}$ & $\begin{array}{c}\text { P- } \\
\text { value }\end{array}$ \\
\hline Stull Run- Conductivity & -0.2 & 0.44 \\
\hline Big Run- Conductivity & 0.01 & 0.96 \\
\hline Big Run- Chloride & 0.5 & 0.21 \\
\hline Short Creek- Conductivity & -0.1 & 0.61 \\
\hline Short Creek- Chloride & -0.07 & 0.75 \\
\hline Short Creek- TSS & 0.06 & 0.78 \\
\hline Girty Run- Conductivity & -0.1 & 0.64 \\
\hline Girty Run- Chloride & -0.14 & 0.53 \\
\hline Weidman Run- Conductivity & 0.01 & 0.94 \\
\hline Weidman Run- Chloride & 0.09 & 0.67 \\
\hline NF Short Creek- Conductivity & -0.32 & 0.12 \\
\hline NF Short Creek- Chloride & -0.33 & 0.12 \\
\hline NF Short Creek- TSS & -0.08 & 0.73 \\
\hline
\end{tabular}

TABLE 2 - Kendall's Tau results 